\title{
PENGARUH NILAI TUKAR RUPIAH TERHADAP RETURN SAHAM PERUSAHAAN INDOFARMA TBK PERIODE 2014-2018
}

\author{
Desy Septariani \\ Program Studi Pendidikan Ekonomi, \\ Fakultas Ilmu Pengetahuan dan Pendidikan Sosial \\ Universitas Indraprasta PGRI \\ desy.septa@gmail.com \\ Dikirim: 14 September 2020; Direvisi: 07 November 2020; Dipublikasikan: 24 Desember 2020
}

\begin{abstract}
ABSTRAK
Return adalah tujuan yang ingin dicapai oleh semua perusahaan. Ada banyak fanyak faktor yang mempengaruhi return salah satunya nilai tukar rupiah. Penelitian ini bertujuan untuk mengetahui pengaruh nilai tukar rupiah terhadap return saham pada perusahaan Indofarma Tbk periode 2014 sampai 2018. Metode penelitian yang digunakan adalah metode kuantitatif. Populasi dalam penelitian ini adalah perusahaan Indofarma Tbk yang terdaftar di Bursa Efek Indonesia tahun 2014 sampai 2018, dengan sampelnya perusahaan indofarma Tbk. Data yang diperlukan dalam penelitian diperoleh dari Bursa Efek Indonesia. Metode analisis yang digunakan adalah regresi linear sederhana. Hasil penelitian menunjukkan bahwa Nilai Tukar Rupiah berpengaruh terhadap Return Saham perusahaan Indofarma Tbk periode 2014 sampai 2018. Untuk penelitian selanjutnya dapat menambah variabel yang mempengaruhi return diantaranya tingkat suku bunga, inflasi,ukuran perusahaan, nilai perusahaan dan juga memperluas sampel penelitian supaya hasil penelitian dapat lebih baik lagi.
\end{abstract}

Kata kunci: Nilai Tukar Rupiah dan return Saham

\begin{abstract}
Return is the purpose to be achieved by all companies. There are many factors that influence the return which is the exchange rate. The purpose of this research is to know the influence of rupiah money exchange to word stock return of Indofarma Tbk company for the period 2014 until 2018. The research method use quantitative method. The Population of this research is Indofarma Tbk company in Indonesian Stock Exchange period 2014 until 2018, With Sampling Indofarma Tbk Company. Data that needed in this research has taken from Indonesian Stock Exchange. The Analysis method that used is simple linear regression analysis by using SPSS. The result of this research show that of rupiah money exchange have significant effect towords stock return of Indofarma Tbk company for period 2014 until 2018. The next research to increase the variables that influences the return are the Interest rate, inflation, size firm, value of firm and also expand the sample to the research results could be better.
\end{abstract}

Keywords: Rupiah money exchange and Stock Return. 


\section{PENDAHULUAN}

Pasar modal (capital market) yaitu pasar atau tempat untuk memperjual belikan berbagai instrumen keuangan jangka panjang yang berupa obligasi, saham, reksa dana, instrumen derivatif dan instrumen lainnya. Pasar modal memiliki peranan yang penting dalam pembangunan ekonomi, karena dengan adanya pasar modal sebuah perusahaan akan mendapatkan aliran dana untuk menjalankan kegiatannya dikarenakan adanya investor yang melakukan investasi di pasar modal, baik itu investor domestik maupun investor asing. Sebelum melakukan investasi, investor bisa menganalisa saham salah satunya dengan mengevaluasi kinerja perusahaan. Hal ini dilakukan oleh investor untuk melihat mana yang akan memberikan return dan risiko yang sesuai dengan harapan mereka.

Ada banyak faktor yang mempengaruhi kinerja dari perusahaan,salah satunya adalah nilai tukar rupiah yang selalu mengalami perubah, perubahan ini mencerminkan bahwa perusahaan tersebut sedang mengalami foreign exchange exposure (eksposur nilai tukar). Perubahan nilai tukar yang tidak bisa diramalkan ini menjadi salah satu penelitian ini dilakukan. Penelitian ini akan melihat pengaruh dari nilai tukar rupiah terhadap return saham. Dari nilai return saham akan kelihatan bagaimana kinerja sebuah perusahaan sehingga investor yang akan berinvestasi dapat menjadikan return saham sebagai salah satu pertimbangan dalam melakukan investasi.

Menurut (Amrillah, 2016) kegiatan di pasar modal dapat dilihat dari harga sahamnya. Harga saham di bursa efek selalu berfluktuasi sehingga mengakibatkan investor tertarik untuk melakukan investasi di pasar modal, hal ini bergantung dengan permintaan dan penawaran. Peningkatan harga saham mencerminkan keadaan pasar sedang bullish atau kemungkinan keuntungan dari harga saham yang meningkat. Apabila harga saham menurun mencerminkan keadaan pasar sedang bearish atau harga pasar bisa jatuh dalam waktu dekat.

Harga saham di Bursa Efek Indonesia akan selalu mengalami fluktuasi. Ini disebabkan oleh faktor ekonomi mikro dan ekonomi makro. Faktor ekonomi mikro adalah faktor-faktor ekonomi yang langsung berkaitan dengan keadaan intern perusahaan, sedangkan untuk faktor ekonomi makro merupakan faktor-faktor yang berhubungan di luar perusahaan. Menurut Tandelilin (2010:343) dalam (Afiyanti \& Topowijono, 2018) menjelaskan bahwa variabel ekonomi makro yang harus menjadi pusat perhatian investor adalah tingkat suku bunga, tingkat inflasi, kurs rupiah, produk domestik bruto (PDB), anggaran defisit, investasi swasta, serta neraca perdagangan dan pembayaran. Variabel yang digunakan dalam penelitian ini adalah faktor ekonomi makro yaitu nilai tukar dikarenakan variable ini termasuk salah satu yang paling mempengaruhi kondisi perekonomian dan hubungannya sangat berkaitan dengan return saham.

Nilai tukar atau kurs merupakan sebuah perjanjian yang dikenal sebagai nilai tukar mata uang terhadap pembayaran saat ini atau dikemudian hari, antara dua mata uang masing-masing negara. Fluktuasi nilai tukar uang sangat mempengaruhi investasi asing yang masuk di Indonesia. Hal terpenting dari nilai tukar rupiah adalah volatilitas nilai tukar rupiah tersebut. Nilai tukar rupiah (kurs) terhadap dolar yang mengalami perubahan akan mempengaruhi besarnya laba dan rugi yang diterima oleh perusahaan, hal ini dikarenakan terjadinya perubahan pemasukan perusahaan dalam bentuk rupiah. Perubahan nilai tukar rupiah tidak bisa diprediksi.

Pada level mikro, hubungan konseptual harga saham perusahaan dan nilai tukar berdasarkan kemampuan daya saing perusahaan tersebut. Fluktuasi nilai tukar secara substansial akan berdampak pada nilai perusahaan baik itu perubahan persaingan, operasional perusahaan, perubahan harga input, dan perubahan dalam nilai mata uang asing yang menjadi aset perusahaan yang akan berpengaruh terhadap harga saham perusahaan

Pada level makro, dampak dari fluktuasi nilai tukar terhadap pasar modal tergantung dari ekonomi perdagangan internasional dan ketidak seimbangan perdagangan dari negara tersebut. Perubahan nilai tukar mata uang merupakan ketidakpastian dalam aspek keuangan yang akan 
mempengaruhi asset dan kewajiban (liabilities) perusahaan. Ketidakpastian ini akan membuat investor berupaya untuk mencari return tertinggi dengan risiko tertentu, salah satunya risiko dari mata uang asing (currency risk). Faktor utama penyebab perubahan harga saham adalah adanya pandangan yang berbeda dari setiap investor yang dapat dilihat melalui ROR (rate of return) yang diinginkan. Jika investor berpendapat ROR saham yang dimiliki tidak bagus, maka investor akan menjual saham sehingga harga saham menjadi turun.

Nilai tukar mata uang menurut FASB adalah rasio antara suatu unit mata uang dengan sejumlah mata uang lain yang bisa ditukar pada waktu tertentu. Perbedaan nilai tukar riil dengan nilai tukar nominal harus untuk dipahami karena keduanya mempunyai pengaruh yang berbeda terhadap risiko nilai tukar (Sartono, 2001) dalam (Suciwati et al., 2002). Perubahan nilai tukar nominal akan diikuti oleh perubahan harga yang sama yang menjadikan perubahan tersebut tidak berpengaruh terhadap posisi persaingan relatif antara perusahaan domestik dengan pesaing luar negerinya dan tidak ada pengaruh terhadap aliran kas. Sedangkan perubahan nilai tukar riil akan menyebabkan perubahan harga relatif (yaitu perubahan perbandingan antara harga barang domestik dengan harga barang luar negeri). Sehingga perubahan tersebut akan mempengaruhi daya saing barang domestik.

Menurut Nopirin (2000:163) dalam (Arifin et al., 2016) kurs adalah pertukaran antara dua mata uang yang berbeda, yang nantinya akan menghasilkan perbandingan nilai ataupun harga dari kedua mata uang tersebut. Metode pembayaran yang dilakukan di dalam negeri ataupun di luar negeri harus terikat dengan nilai tukar atau kurs. Apabila mata uang suatu negara nilainya mengalami peningkatan, maka Negara tersebut disebut sedang mengalami apresiasi. Sedangkan jika nilai mata uang suatu negara mengalami penurunan, maka Negara tersebut disebut sedang mengalami depresiasi. Nilai Kurs Tukar Rupiah menurut

Fabozzi dan Franco (1996) dalam (Prasetioningsih et al., 2018) nilai kurs adalah: "an exchange rate is defined as the amount of one currency that can be exchange per unit of another currency, or the price of one currency in items of another currency".

Nilai tukar mata uang akan berdampak terhadap pergerakan harga saham. Dengan terjadinya inflasi, hubungan nilai tukar dan harga saham menjadi negatif. Pada saat inflasi meningkat, nilai tukar akan naik karena hilangnya nilai mata uang domestik. Dengan meningkatnya inflasi membuat ekspektasi investor terhadap permintaan pada risk premium dan rate of return yang paling tinggi sehingga harga saham akan turun. Sistem pembayaran di dalam negeri ataupun di luar negeri harus terikat dengan nilai tukar atau kurs. Robert Gilpin (2001 : 183) dalam (Arifin et al., 2016) menjelaskan bahwa system nilai tukar terdiri dari dua macam yaitu:

1. Kurs tetap atau Fixed Exchange Rate. Kurs ini merupakan sistem nilai tukar dimana bank central sebagai pemegang otoritas moneter tertinggi negara menetapkan nilai tukar dalam negeri terhadap negara lain yang ditetapkan pada tingkat tertentu tanpa melihat aktivitas penawaran dan permintaan di pasar uang, yaitu dengan mengaitkan nilai suatu mata uang dengan emas.

2. Kurs bebas. Kurs ini Terjadi apabila perbandingan nilai mata uang suatu negara dengan mata uang negara lain dibiarkan untuk ditentukan secara bebas oleh tarik menarik kekuatan pasar atau sesuai permintaan dan penawaran. Sistem kurs bebas disebut juga sebagai kurs devisa mengambang. System ini terdiri dari dua yaitu yang pertama Kurs Mengambang Terkendali (Managed Floating Exchange Rate). Pada kurs ini pemerintah tetap bisa mengambil kebijakan intervensi yang diperlukan. Artinya penetapan kurs tidak diserahkan secara penuh kepada aktivitas pasar valas. Kurs yang kedua adalah Kurs Mengambang Bebas (Free Floating Rate). Kurs ini sangat pas atau cocok diterapkan oleh Negara yang kondisi perekonomiannya sudah maju dan mapan, dikarekan sistim nilai tukar ini menyerahkan 


\section{sosio e-kons}

Volume 12, No. 3, Desember 2020, pp. 221-229

e-ISSN: $2502-5449$

p-ISSN: 2085-2266

DOI : 10.30998/sosioekons.v12i3.7548

seluruhnya kepada pasar untuk mencapai kondisi ekuilibrium yang sesuai dengan keadaan internal dan eksternal negara bersangkutan. Jadi dapat disimpulkan dalam sistem nilai tukar ini seharusnya tidak ada campur tangan pemerintah.

Di BEI selain obligasi dan sertifikat, saham juga ikut diperdagangkan. Saham merupakan salah satu tanda bukti kepemilikan yang diserahkan pada pihak pengelola setoran modal,dan mempunyai hak sesuai dengan jenis saham yang dimiliki. Saham adalah tanda penyertaan atau pemilikan seseorang atau badan dalam suatu perusahaan. Perusahaan menjual saham kepada masyarakat dengan tujuan agar mendapatkan dana dengan lebih murah. Investor yang melakukan pembelian saham akan mendapatkan keuntungan berupa dividen dan capital gain. Dividen merupakan pembagian keuantungan yang diberikan oleh perusahaan yang berasal dari keuntungan yang diperoleh perusahaan. Capital gain merupakan selisih antaa harga beli dan harga jual. Capital Gain terbentuk dengan adanya aktivitas perdagangan saham di pasar sekunder.

Dalam melakukan investasi selain memperhatikan Return Saham, investor juga harus memperhatikan risiko dalam investasi yang dilakukan (Prasetioningsih et al., 2018). Hal ini dikarenakan risiko dan return memliki hubungan yang postif, jika risiko yang dihadapi tinggi, maka semakin tinggi juga return dikompensasikan. Komponen pengembalian return saham ada dua yaitu pertama Capital Gain yang merupakan keuntungan bagi investor yang diperoleh dari kelebihan harga jual di atas harga beli yang keduanya terjadi di pasar sekunder. Komponen kedua adalah Yield yang merupakan pendapatan atau aliran kas yang diterima secara periodik. Misalnya berupa deviden atau bunga.

Return Saham adalah suatu nilai atau imbalan yang didapatkan dari kegiatan investasi yang dilakukan yang meliputi deviden bagi investasi saham dan pendapatan bunga bagi investasi surat utang. Return inilah yang memotivasi investor untuk investasi pada perusahaan. "Tandelilin (2010) dalam (Siska \& Arigawati, 2020) mengemukakan bahwa: "Return merupakan salah satu faktor yang memotivasi investor berinteraksi dan juga apresiasi yang diberikan atas keberanian investor dalam menanggung risiko atas investasi yang dilakukannya." Perusahaan yang memiliki return saham yang tinggi akan mudah menarik minat investor untuk membeli saham perusahaannya. . Return saham ini akan sangat dirasakan lebih penting ketika investor akan melakukan investasi. Para investor akan berfikir bagaimana cara agar return yang mereka terima bisa maksimal.

Return terdiri dari dua bagian yaitu pertama return realisasi yang disebut juga dengan actual return yang digunakan sebagai dasar dalam menentukan return ekspektasi dan tingkat risiko yang akan dihadapi. Return realisasi dihitung dengan menggunakan data historis. Return ini juga digunakan untuk mengukur kinerja perusahaan. Jogiyanto (2000) (Prasetioningsih et al., 2018), mengemukakan bahwa Pengukuran return realisasi yang banyak digunakan adalah sebagai berikut:

1. Return Total. Return Total merupakan return realisasi keseluruhan dari suatu investasi dalam suatu periode yang tertentu. Return Total sering disebut dengan return saja

2. Relatif Return. Relatif Return dapat digunakan, yaitu dengan menambahkan 1 terhadap nilai return total

3. Kumulatif Return. Indeks kemakmuran kumulatif (cumulatif Wealth Index) digunakan untuk mengukur akumulasi semua return mulai dari kemakmuran awal yang dimiliki.

4. Return Disesuaikan. Return disesuaikan disebut juga return riel (real return) adalah return yang disesuaikan dengan tingkat inflasi

5. Return rata-rata geometric.Return rata-rata geometrik digunakan untuk menghitung rata-rata yang memperhatikan tingkat pertumbuhan kumulatif dari waktu ke waktu 
Bagian return yang kedua adalah return harapan yang biasa disebut dengan expected return. Menurut Ismanto (2009) dalam (Siska \& Arigawati, 2020) Jika tingkat risiko yang akan dihadapi oleh investor tinggi, maka return harapannya juga akan lebih tinggi. Expected return digunakan untuk pengambilan keputusan investasi. Return ini menjadi lebih penting dibandingkan dengan return historis (realisasi) dikarenakan return ini yang diharapkan oleh semua investor di masa yang akan datang. Ada beberapa cara yang digunakan dalam menghitung return ekspetasian (expected return) yaitu

1. Berdasarkan nilai ekspetasian masa depan,

2. Berdasarkan nilai-nilai return historis,

3. Berdasarkan model return ekspetasian yang ada.

Salah satu yang mempengaruhi return saham adalah nilai tukar rupiah. Return saham dan nilai tukar rupiah umumnya dipengaruhi oleh faktor-faktor fundamental dan teknikal.(Saputra \& Dharmadiaksa, 2016). Bramantyo (2006) dalam (Prasetioningsih et al., 2018) menyatakan mengatakan bahwa terdapat dua macam analisis yang digunakan untuk menentukan Return Saham, yaitu pertama informasi fundamental perusahaan dan yang kedua adalah informasi teknikal. Informasi fundamental adalah informasi yang berasal dari intern perusahaan. Informasi ini meliputi deviden dan tingkat pertumbuhan penjualan perusahaan. informasi teknikal merupakan informasi yang berasal dari luar perusahaan seperti ekonomi, politik, dan finansial. Kedua informasi ini bisa digunakan oleh investor sebagai faktor untuk memprediksi Return Saham.

Return saham dihitung dengan menggunakan rumus sebagai berikut:

$$
\begin{aligned}
& \text { Return } \\
& \text { Saham }
\end{aligned} \quad=\frac{\mathrm{Pt}-\mathrm{Pt}-1+\mathrm{Dt}}{\mathrm{Pt}-1}
$$

Sumber: Hartono (2014:237) dalam (Afiyanti \& Topowijono, 2018)

Keterangan:

Pt : harga saham bulan sekarang

Pt-1 : harga saham bulan sebelum

Dt : dividen yang dibayarkan pada bulan sekarang

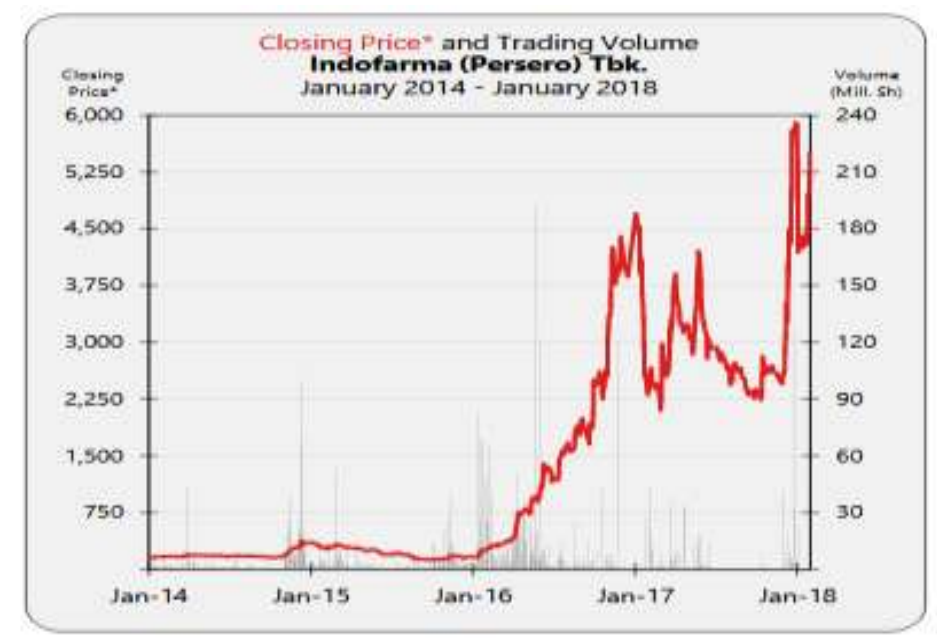

Closing Price and Trading Volume PT. Indofarma Tbk. Sumber https://www. idx.co.id (2018) 
Volume 12, No. 3, Desember 2020, pp. 221-229

e-ISSN: $2502-5449$

p-ISSN: 2085-2266

DOI : 10.30998/sosioekons.v12i3.7548

Data grafik di atas adalah closing price and trading volume pada PT.Indofarma selama periode 2014 sampai 2018 PT. Indofarma mengalami kenaikan dari harga penutupan mulai dari Januari 2014 sebanyak kurang dari 750 hingga mencapai hampir 6,000 pada Januari 2018 dengan volume atau jumlah lembar saham yang ditransaksikan mencapai 210 Miliyar.

Ada beberapa penelitian terdahulu yang sudah dilakukan dan kesimpulan hasilnya ditemukan bahwa nilai tukar rupiah berpengaruh terhadap return saham. Penelitian yang dilakukan oleh (Pujawati et al., 2015) tentang pengaruh nilai tukar rupiah terhadap return saham dengan profitabilitas sebagai variable intervening. Penelitiannya menghasilkan bahwa nilai tukar berpengaruh negatif dan signifikan terhadap return saham yang artinya jika nilai rupiah melemah maka akan meningkatkan return saham perusahaan. Begitu juga dengan penelitian yang dilakukan oleh (Amrillah, 2016) mengenai pengaruh nilai tukar rupiah (Kurs), Inflasi dan pertumbuhan ekonomi terhadap return saham pada perusahaan perbankan yang terdaftar di Bursa Efek Indonesia yang menghasilkan bahwa nilai tukar rupiah berpengaruh negatif terhadap return saham. Lain hal nya dengan penelitian yang dilakukan oleh (Afiyanti \& Topowijono, 2018) tentang pengaruh inflasi, BI rate dan nilai tukar terhadap return saham. Penelitiannya membuktikan bahwa nilai tukar secara parsial berpengaruh signfikan terhadap return saham perusahaan subsektor food \& beverages yang terdaftar di Bursa Efek Indonesia periode 2013-2016. Penelitian yang dilakukan oleh (Abdallah, 2018) menghasilkan bahwa tidak terdapat pengaruh yang signifikan antara nilai tukar rupiah terhadap return saham pada perusahaan rokok. Begitu juga dengan penelitian yang dilakukan oleh (Zuleli \& Wulansari Yusniar, 2013) yang menghasilkan bahwa tidak ada pengaruh yang signifikan antara nilai tukar rupiah dengan return saham food and baverage. Dilihat dari masih banyaknya perbedaan hasil penelitian, maka peneliti tertarik ingin meneliti lebih lanjut tentang variabel ekonomi makro yaitu nilai tukar rupiah dengan return saham pada perusahaan Indofarma Tbk tahun 2014 sampai 2018.

\section{METODE}

Penelitian ini dilaksanakan di Bursa Efek Indonesia (BEI) melalui website www.idx.co.id yang telah mempublikasikan laporan keuangan tahunannya mengenai closing price dan share trande pada PT. Indofarma Tbk perode 2014 sampai 2018.

Populasi dalam penelitian ini adalah laporan keuangan perusahaan Indofarma Tbk yang terdaftar di BEI mulai dari sejak berdiri sampai listing di BEI. Untuk sampel yang diambil adalah laporan keuangan perusahaan Indofarma Tbk periode 2014 sampai 2018. Data yang digunakan dalam penelitian ini adalah data sekunder berupa laporan keuangan tahunan dan annual report yang bersumber dari situs Bursa Efek Indonesia, sehingga penelitian ini metode pengumpulan data yang digunakan adalah dokumentasi

\section{HASIL DAN PEMBAHASAN}

Berdasarkan hasil pengujian yang telah dilakukan. Maka hasil perhitungan regresi liner sederhana dapat dilihat pada tabel dibawah ini:

Tabel 1. Hasil Regresi linier Sederhana

\begin{tabular}{lcccccccc}
\hline & \multicolumn{3}{c}{ Standard } & & & & \\
& Coefficients & Error & t Stat & P-value & Lower 95\% & Upper 95\% & Lower 95,0\% & Upper 95,0\% \\
\hline Intercept & $-27122,94027$ & 19365,66909 & 1,400568198 & 0,255854576 & $-88753,14233$ & 34507,26178 & $-88753,14233$ & 34507,26178 \\
$(\mathrm{X})$ & 2,266564497 & 1,431389559 & 1,583471448 & 0,211475961 & $-2,288755915$ & 6,821884908 & $-2,288755915$ & 6,821884908 \\
\hline
\end{tabular}

Sumber : Data yang telah diolah oleh Penulis 
Volume 12, No. 3, Desember 2020, pp. 221-229

e-ISSN: $2502-5449$

p-ISSN: 2085-2266

DOI : 10.30998/sosioekons.v12i3.7548

Dari hasil perhitungan di atas diperoleh Persamaan Regresinya $\mathrm{Y}=-271177,94027+$ $2,266564497 X$. Ini berarti jika nilai variabel X yaitu, Kurs Rupiah tetap atau bernilai nol maka akan dapat menurunkan Return Saham sebanyak - 2771177,94027.

Tabel 2. Regresi linear sederhana

\begin{tabular}{lr}
\hline & Regression Statistics \\
\hline Multiple R & 0,674741843 \\
R Square & 0,455276555 \\
Adjusted R Square & 0,273702074 \\
Standard Error & 2635,429116 \\
Observations & 5 \\
\hline
\end{tabular}

Dari tabel di atas dapat dilihat nilai Koefisien Korelasi hasil perhitungan diperoleh sebesar $r=0,674742$ yang bernilai positif. Ini menunjukkan apabila nilai tukar mengalami kenaikan maka Return saham juga mengalami kenaikan sebesar 0,674742. Hal ini dikarenakan dengan meningkatnya nilai kurs, makan akan mengurangi biaya perusahaan.

Untuk melihat seberapa besar pengaruh kekuatan variabel bebas terhadap variabel terikatnya dapat dilihat dari nilai koefisien determinan. Berdasarkan hasil pengujian diperoleh nilai koefisien determinan sebersar $45,52 \%$. Hal ini menunjukkan bahwa pada perusahaan Indofarma Tbk return sahamnya dipengaruhi oleh nilai tukar rupiah sebesar 45,52\% sedangkan sisanya $54,48 \%$ dipengaruhi oleh faktor lain seperti inflasi, pertumbuhan ekonomi, suku bunga dan factor makro dan mikro yang lainnya. berikut:

Berdasarkan hasil pengujian hipotesis dengan menggunakan uji t, maka diperoleh sebagai

Tabel 3. Tabel uji t t-Test:Two-Sample Assuming Equal Variances

\begin{tabular}{lrr}
\hline & $(X)$ & \multicolumn{1}{c}{$(Y)$} \\
\hline Mean & 13504,2 & 3485,2 \\
Variance & 847475,2 & 9562861,7 \\
Observations & 5 & 5 \\
Pooled Variance & 5205168,45 & \\
Hypothesized Mean Difference & 0 & \\
Df & 8 & \\
t Stat & $6,943476765 \quad(\mathrm{t}-$ hitung $)$ \\
$\mathrm{P}(\mathrm{T}<=\mathrm{t})$ one-tail & $5,95982 \mathrm{E}-05$ & \\
t Critical one-tail & $1,859548033 \quad(\mathrm{t}-$ tabel $)$ \\
$\mathrm{P}(\mathrm{T}<=\mathrm{t})$ two-tail & 0,000119196 & \\
t Critical two-tail & 2,306004133 & \\
\hline Sumber : Data Primer yang telah diolah oleh Penulis
\end{tabular}

Dari hasil perhitungan di atas diperoleh nilai t-hitung sebesar 6,943476765 lebih besar dari t- tabel yaitu 1,859548033 yang berarti bahwa Nilai Tukar Rupiah berpengaruh terhadap Return Saham perusahaan Indofarma Tbk. Ini menunjukkan bahwa tinggi rendahnya perubahan return saham dipengaruhi oleh nilai tukar rupiah. Apabila nilai tukar rupiah mengalami peningkatan, maka akan meningkatkan nilai return saham perusahaan. Dengan meningkatnya 
nilai tukar rupiah maka akan menciptakan kondisi ekonomi Negara menjadi lebih baik, yang ditandai dengan kemampuan perusahaan dalam meningkatkan laba perusahaan. Apabila laba perusahaan meningkat maka akan memberikan sinyal yang positif kepada investor yang dapat meningkatkan harga saham perusahaan. Dengan menguatnya harga saham perusahaan, maka akan meningkatkan return saham perusahaan tersebut. Dalam kondisi ini berarti depresiasi nilai tukar akan menurunkan nilai return saham sedangkan apresiasi nilai tukar akan meningkatkan nilai return saham. Nilai tukar mempunyai pengaruh yang signifikan terhadap return saham karena kuat ataupun lemahnya nilai tukar rupiah terhadap mata uang asing sering menjadi penyebab naik turunnya harga saham di bursa efek. Meningkatnya nilai tukar rupiah (Kurs) juga akan meningkatkan pertumbuhan ekonomi melalui perdagangan internasional yang dibuktikan dengan kesejahteraan masyarakat. Pertumbuhan ekonomi yang mengalami peningkatan akan mendorong terjadinya peningkatan permintaan atau kemampuan daya beli masyarakat yang secara langsung akan mempengaruhi investasi di pasar modal. Dengan semakin bertambahnya investasi dipasar modal, maka harga saham akan mengalami kenaikan dan mengakibatkan retur saham juga naik.

Hasil penelitian ini tidak sejalan dengan penelitian yang dilakukan oleh I Gede Agus Angga Saputra., Dan Ida Bagus Dharmadiaksa. (2016). Dimana penelitiannya menghasilkan bahwa nilai tukar rupiah berpengaruh negatif pada return saham pada perusahaan perhotelan. Ini membuktikan bahwa dengan melemahnya nilai tukar rupiah terhadap US\$ akan meningkatkan return saham perusahaan perhotelan. Begitu juga dengan penelitian yang dilakukan oleh (Zuleli \& Wulansari Yusniar, 2013) yang menghasilkan bahwa tidak ada pengaruh yang signifikan antara nilai tukar rupiah dengan return saham food and beverage, artinya peningkatan nilai tukar rupiah tidak berpengaruh terhadap return saham perusahaan food and beverage. Penelitian yang dilakukan oleh (Abdallah, 2018) juga membuktikan tidak adanya pengaruh yang signifikan antara nilai tukar rupiah dengan return saham pada perusahaan rokok. Hasil penelitian ini sejalan dengan yang dilakukan oleh Devi Prasetioningsih., dan Edward Gagah Purwana., \& Taunay \& Azis Fathoni . (2015), yang menghasilkan bahwa nilai tukar rupiah berpengaruh positif dan signifikan terhadap return saham pada perusahaan Lq45 yang terdaftar di BEI periode 2012-2015.

\section{SIMPULAN}

Berdasarkan dari hasil penelitian, maka dapat disimpulkan bahwa Nilai Tukar Rupiah berpengaruh positif terhadap Return Saham pada perusahaan Indofarma Tbk periode 20142018. Hal ini berarti dengan nilai tukar rupiah yang meningkat, maka akan meningkatkan return saham perusahaan indofarma Tbk. Dalam kondisi ini dikatakan bahwa depresiasi nilai tukar akan mengakibatkan turunnya nilai return saham sedangkan apresiasi nilai tukar akan mengakibatkan peningkatan nilai return saham perusahaan.

\section{DAFTAR RUJUKAN}

Abdallah, Z. (2018). Pengaruh Nilai Tukar Rupiah Terhadap Return Saham Dengan Return On Asset Sebagai Variabel Intervening pada Perusahaan Rokok. Journal Akuntansi, 14(1), 1-10. https://doi.org/http://dx.doi.org/10.24217

Afiyanti, H. T., \& Topowijono. (2018). Pengaruh Inflasi, BI Rate dan Nilai Tukar Terhadap Return Saham (Studi Pada Perusahaan Subsektor Food \& Beverages 
Yang Terdaftar Di Bursa Efek Indonesia Periode 2013-2016). Jurnal Administrasi Bisnis, 61(2), 144-151.

http://administrasibisnis.studentjournal.ub.ac.id/index.php/jab/article/view/2583

Amrillah, M. F. (2016). Pengaruh Nilai Tukar Rupiah (Kurs), Inflasi Dan Pertumbuhan Ekonomi Terhadap Return Saham Pada Perusahaan Perbankan Yang Terdaftar Di Bursa Efek Indonesia (Bei) Periode 2008-2014. Jurnal Valuta, 2(2), 232-250.

Arifin, Z., Masri, H., \& Hadi, S. (2016). Nilai Tukar Dan Kedaulatan Rupiah. Jurnal Sosio-E-Kons, 8(1), 62-71.

Prasetioningsih, D., Taunay, E. G. P., \& Fathoni, A. (2018). Pengaruh Nilai Tukar Rupiah Terhadap Return Saham Yang Terdaftar Di Bursa Efek Indonesia (Studi Kasus Perusahaan LQ 45 Periode Januari 2012- Desember 2015). Jurnal of Management, 4(4), 1-10.

Pujawati, P. E., Wiksuana, I. G. B., Gede, L., \& Artini, S. (2015). Pengaruh Nilai Tukar Rupiah terhadap Return Saham Dengan Profitabilitas sebagai variabel intervening. E-Jurnal Ekonomi Dan Bisnis Universitas Udayana, 4.04, 220-242. https://media.neliti.com/media/publications/44731-ID-pengaruh-nilai-tukar-rupiahterhadap-return-saham-dengan-profitabilitas-sebagai.pdf

Saputra, I. G. A., \& Dharmadiaksa, I. B. (2016). Pengaruh Tingkat Suku Bunga, Nilai Tukar Rupiah, Leverage Dan Profitabilitas Pada Return Saham. E-Jurnal Akuntansi Universitas Udayana, 16(45), 1003-1033. https://ojs.unud.ac.id/index.php/Akuntansi/article/view/20600/15110

Siska, E., \& Arigawati, D. (2020). Reaksi Ramadhan Effect terhadap Saham Perusahaan Makanan dan Minuman di Indonesia. Journal of Applied Business and Economics (JABE), 6(4), 330-340. https://doi.org/10.1017/CBO9781107415324.004

Suciwati, D. P., Machfoedz, M., \& Universitas. (2002). Pengaruh Risiko Nilai Tukar Rupiah terhadap Return Saham: Studi Empiris pada Perusahaan Manufaktur yang terdaftar di BEJ. Jurnal Ekonomi \& Bisnis Indonesia (Fakultas Ekonomi Dan Bisnis Universitas Gadjah Mada), 17(4), 347-360. https://doi.org/10.22146/jieb.6815

Zuleli, R., \& Wulansari Yusniar, M. (2013). Pengaruh Tingkat Keuntungan Pasar, Nilai Tukar Rupiah, Inflasi, Dan Tingkat Suku Bunga, Terhadap Return Saham Industri Food And Baverage Tahun 2007-2009 Studi Pada Bursa Efek Indonesia. Jurnal Wawasan Manajemen, 1(1), 105-128. 